\title{
PENINGKATAN PRODUKTIVITAS SAPI POTONG MELALUI INTRODUKSI PAKAN KONSENTRAT DENGAN BAHAN LOKAL PADA MASYARAKAT ASLI PAPUA
}

\section{Increased Productivity of Beef Cattle through Introduction Feed Concentrates with The Local Papuan}

\author{
Andoyo Supriyantono*, Deny Anjelus Iyai, Abdul Rahman Ollong \\ Fakultas Peternakan Universitas Papua \\ Jl. Gunung Salju, Amban, Manokwari 98314, Papua Barat, Indonesia
}

Article history

Received: Juli 3, 2020;

Accepted: Oktober 22, 2020

* Corresponding author:

E-mail:

andoyo@yahoo.com

DOI: https://doi.org/10.465

49/igkojei.v1i1.126

\section{ABSTRACT}

Beef cattle are one of livestock which are kept by Papuan. Generally, the pattern of beef cattle keeping is extensively - let the cattle are as scavenger in palm plantation or tied them around the house. In the last seven years, more Papuan were keeping beef cattle due to the government introduced beef cattle to Papuan as one of dowry. The purpose of community service program-community empowerment learning (KKN-PPM) was 1. Optimal use of agricultural waste as tofu waste, rice bran, peel of cocoa, cassava and its by-products for additional feed of beef cattle; 2. Reduced dependence on additional feed from factories. KKN-PPM was carried out in Waseki Pop, Prafi District for 67 days. KKN-PPM was commenced from provisioning to students concerning potential of feeding; the development of feed technology; complete feed and feed concentrate. Local feed materials for making feed concentrate were rice brand (70\%), stacks $(16 \% 0)$, waste product of tofu $(11 \%)$, salt $(2 \%)$ and urea $(1 \%)$. Those compositions were met the requirement of dry matter and crude protein for beef cattle. 30 students from different field study joined for the KKN-PPM program. Workload of each student was calculated based on the effective working time (EWT) which was about 288 EWT. The method of implementing KKN-PPM starts from debriefing students on campus, namely the use of potential feed; feed technology development; complete feed and concentrate. During the implementation in the field, students and their supervisors conducted technical guidance on beef cattle maintenance, concentrate processing techniques and counseling for cattle breeders. During the KKN-PPM activities, a total of 114.4 $\mathrm{kg}$ of concentrate was given to 7 cows. Sustainability of the program would be reached when government of West Papua and Manokwari district had the same program for students every year to make feed concentrate for farmers.

Keywords: Feed concentrate; Local material feed; Beef cattle

\section{ABSTRAK}

Sapi merupakan salah satu ternak yang dijadikan usaha sambilan bagi penduduk asli Papua. Pola pemeliharaan sapi pada umumnya dilakukan secara ekstensif yaitu sapi dibiarkan berkeliaran di perkebunan kelapa sawit atau diikat di sekitar rumah. Tujuh tahun terakhir ini, masyarakat asli Papua banyak mengusahakan sapi potong setelah Bupati Manokwari dengan kesepakatan Lembaga Masyarakat Adat memperkenalkan sapi potong sebagai salah satu bentuk mas kawin. Tujuan dilaksanakan Kuliah Kerja Nyata Pembelajaran Pemberdayaan Masyarakat (KKN-PPM) adalah 1. pemanfaatan secara optimal limbah pertanian untuk pakan tambahan sapi potong; 2. Berkurangnya ketergantungan pakan tambahan dari pabrik. KKN-PPM dilaksanakan selama 67 hari di Kampung Waseki Pop Distrik Prafi. Kegiatan ini diikuti oleh 30 
mahasiswa secara terpadu dari berbagai bidang ilmu. Volume pekerjaan setiap mahasiswa dihitung berdasarkan Jam Kerja Efektif Mahasiswa yakni sebanyak 288 JKEM. Metode pelaksanaan KKN-PPM dimulai dari pembekalan mahasiswa di kampus yaitu pemanfaatan bahan pakan potensial; pengembangan teknologi pakan; pakan komplit dan konsentrat. Dalam pelaksanaan di lapang, mahasiswa bersama-sama dosen pembimbing melakukan bimbingan teknis pemeliharaan sapi potong, teknik membut konsentrat dan penyuluhan kepada peternak sapi. Konsentrat dibuat dari bahan-bahan lokal setempat yaitu dedak padi (70\%), onggok (16), ampas tahu (11\%), garam (2\%) dan urea (1\%). Dengan formulasi konsentrat seperti tersebut maka kebutuhan bahan kering dan protein kasar sapi potong telah memenuhi standar. Selama kegiatan KKN-PPM, total konsentrat yang dibuat sebanyak $114,4 \mathrm{~kg}$ yang diberikan pada 7 ekor sapi. PEMDA Provinsi Papua Barat dan Kabupaten Manokwari diharapkan mempunyai program yang sama setiap tahunnya untuk mendanai kegiatan pendampingan dalam pembuatan konsentrat pada wilayah-wilayah binaannya

Kata kunci: Konsentrat; Bahan lokal; Sapi potong

\section{PENDAHULUAN}

Sapi merupakan salah satu ternak yang dipelihara dan dijadikan sebagai usaha sambilan bagi penduduk asli Papua yang tinggal di Distrik Prafi. Mata pencaharian utama penduduk adalah petani dengan mengusahakan tanaman perkebunan seperti coklat, kelapa sawit, dan tanaman hortikultura. Pola pemeliharaan sapi pada umumnya dilakukan secara ekstensif yaitu sapi dibiarkan berkeliaran di perkebunan kelapa sawit atau diikat di sekitar rumah. Hal ini berdampak pada pola penyediaan pakan ternak sapi. Ternak sapi yang dilepasliarkan di sekitar perkampungan dan di bawah naungan kelapa sawit mengkonsusmsi hijauan yang tumbuh di bawah pohon kelapa sawit dan atau di sekitar perkampungan. Sapi-sapi yang diikat dan memiliki areal jelajah terbatas hanya mengkonsusmsi hijauan yang ada di tempat dimana ternak sapi diikat dan tidak pernah mendapat makanan tambahan sebagai asupan gizi. Model pemeliharaan seperti ini menyebabkan produktivitas sapi tidak maksimal. Ternak sapi mudah terserang penyakit cacingan dan sistem perkawinan yang tidak terkontrol.

Tujuh tahun terakhir ini, masyarakat asli Papua banyak mengusahakan sapi potong setelah Bupati Manokwari dengan kesepakatan Lembaga Masyarakat Adat Kabupaten Manokwari memperkenalkan sapi potong sebagai salah satu bentuk mas kawin selain babi pada masyarakat asli Papua. Berdasarkan data dari Badan Pusat Statistik Provinsi Papua Barat, jumlah sapi potong di Kabupaten Manokwari pada tahun 2018 sebanyak 16.857 ekor, 10-15 persen diantaranya dimiliki oleh masyarakat asli Papua. Peningkatan produktivitas sapi potong pada masyarakat asli Papua layak dilakukan karena mereka ikut berperan dalam mensukseskan program swasembada daging sapi yang telah dicanangkan pemerintah.

Peningkatan produksi dan produktivitas ternak sapi dapat ditingkatkan melalui pemberian pakan tambahan yang teratur dan benar. Pertambahan bobot badan (PBB) sapi Bali yang diberi pakan suplemen Blok multinutrien dari limbah sawit (lumpur sawit /Lam Blok dan serat sawit/Sam Blok) berbasis bahan pakan lokal sebesar 0.3 - 0.4 gram/ekor/hari dan meningkatkan efisiensi ransum (1.2-2.9) (Abutani et al, 2010). Hasil penelitian Handiwirawan dan Tiesnamurti (2015) juga memperoleh PBB yang sama yaitu sebesar 0,303 kg/ekor/hari. Nanda et al (2014) menyatakan bahwa pertambahan bobot badan harian sapi bali yang diberi pakan dengan berbagai level pelepah sawit yaitu berkisar antara $0,3-0,42 \mathrm{~kg} / \mathrm{hari}$. Namun demikian pada pola pemeliharaan sapi bali yang tidak terkontrol di padang penggembalaan yang didominasi alang-alang maka pemberian pakan tambahan tidak berpengaruh terhadap pertambahan berat badan ternak (Rauf et al, 2015). Disisi lain, Sari et al (2016) menyatakan bahwa pemberian pakan hijauan dan pakan tambahan berupa ampas tahu $2 \mathrm{~kg}$ dan limbah bioethanol padat $200 \mathrm{~g}$, limbah cair $100 \mathrm{ml}$ berpengaruh 
terhadap penampilan sapi Bali, yaitu meningkatkan konsumsi pakan $\left(6,97 \mathrm{~kg} \mathrm{hari}^{-1}\right)$, menaikkan bobot badan $\left(0,64 \mathrm{~kg}\right.$ hari $\left.^{-1}\right)$ dan menurunkan nilai konversi pakan sapi Bali $(10,94)$.

Kegiatan operasional untuk pengembangan usaha perbibitan sapi potong yang murah dan efisien dapat dilakukan secara terintegrasi dengan perkebunan, tanaman pangan, dan memanfaatkan sumber pakan biomas lokal. Melalui inovasi teknologi limbah dan sisa hasil ikutan agroindustri pertanian dapat dimanfaatkan sebagai sumber pakan sapi yang potensial untuk usaha penggemukan dan pembibitan (Mariyono dan Romjali, 2007). Bahan pakan asal biomas lokal yang berharga murah pada umumnya mempunyai keterbatasan kualitas karena kandungan protein, TDN, palatabilitas, dan kecernaan yang rendah. Namun demikian bahan pakan tersebut dapat digunakan secara optimal sebagai pakan basal dan telah terbukti selain dapat menurunkan biaya ransum juga mampu meningkatkan produktivitas ternak.

Usaha dalam meningkatkan produktivitas sapi potong di Distrik Prafi mutlak dilakukan agar masyarakat asli Papua dapat berdiri sejajar dengan masyarakat lain yang telah terlebih dahulu mengenal pemeliharaan sapi potong. Namun demikian usaha-usaha tersebut bukan hal yang mudah terutama menyangkut pergeseran budaya dari ternak babi ke ternak sapi potong, mengakibatkan terjadinya perubahan dalam teknik pemeliharaan ternak. Hal pokok yang harus dicari pemecahannya adalah bagaimana ketersediaan paket teknologi yang sesuai untuk dilaksanakan oleh petani, bagaimana keterampilan itu sampai kepada petani dan bagaimana petani dapat digerakkan. Pemecahan masalah juga harus mempertimbangkan sosial ekonomi petani dan kelembagaankelembagaan yang ada di tingkat pedesaan. Hal yang penting juga adalah bagaimana tersedianya sarana dan alat serta dana yang dapat dijangkau oleh kemampuan petani itu sendiri.

Keterlibatan Perguruan Tinggi seperti UNIPA Manokwari dalam mengatasi masalah-masalah tersebut di atas perlu dilakukan terutama dengan melibatkan para mahasiswa melalui suatu kegiatan Kuliah Kerja Nyata. Mahasiswa perlu dilatih secara dini untuk menyelesaikan masalah-masalah yang ada di tingkat masyarakat sehingga kelak telah siap menjadi sarjana mandiri. Pemda Provinsi Papua Barat juga harus peduli terhadap masalah-masalah yang dihadapi oleh petani di lingkup wilayah kerjanya terutama Dinas Peternakan dan Kesehatan Hewan yang membawahi bidang peternakan. Dinas ini perlu dilibatkan sebagai mitra mengingat keberlanjutan program pembinaan masyarakat setelah program KKN-PPM berakhir.

Desa Waseki Pop merupakan salah satu desa yang terletak pada Distrik Prafi Kabupaten Manokwari Papua Barat (peta terlampir). Sebanyak 99\% masyarakat yang mendiami desa Waseki Pop adalah warga lokal dari suku Meyah dan atau Mandacan yang melakukan transmigrasi lokal pada tahun 1980-an. Desa ini terdiri dari tiga jalur dengan jumlah rumah sebanyak 20 rumah. Dalam satu rumah didiami oleh 2-3 Kepala Keluarga. Total jumlah penduduk sebanyak 86 jiwa. Setiap rumah dilengkapi dengan listrik, air bersih dan fasilitas MCK yang diperoleh dari bantuan proyek PNPM Mandiri. Sebagian besar penduduk bermata pencaharian sebagai petani dengan menanam cabe, batatas dan keladi. Hasil kebun biasanya digunakan untuk kebutuhan sehari-hari (petani subsistem) bukan untuk dijual. Sumber protein hewani diperoleh dari ikan yang berasal dari sungai dan beberapa satwa liar seperti burung, tikus tanah, ular dan lain-lain yang diperoleh dari hutan. Ternak yang dipelihara adalah babi, ayam, dan sapi. Pada tahun 1999 masyarakat memperoleh bantuan perkandangan untuk ayam buras dari Dinas Peternakan Kabupaten Manokwari. Sapi Bali pertama kali dipelihara pada tahun 1993 dengan bantuan bergulir dari pemerintah daerah. Perkembangan sapi sangat pesat karena mudah dalam memperoleh hijauan dan lahan penggembalaan masih sangat luas. Akses ke desa Waseki Pop dilakukan dengan jalan darat dari ibukota kabupaten dengan jarak tempuh sekitar $86 \mathrm{~km}$. Tujuan dilaksanakan KKN-PPM adalah:

a. Pemanfaatan secara optimal limbah pertanian berupa ampas tahu, dedak, kulit kakao, singkong, dan hasil ikutannya untuk pakan tambahan sapi potong;

b. Berkurangnya ketergantungan pakan tambahan dari pabrik yang harganya mahal; 


\section{METODE}

\section{PERSIAPAN DAN PEMBEKALAN}

\section{MEKANISME PELAKSANAAN KEGIATAN KKN-PPM}

Mekanisme pelaksanaan kegiatan KKN-PPM dilaksanakan dalam beberapa tahapan sebagai berikut:

- Tahap 1, memberikan pembekalan kepada mahasiswa peserta KKN-PPM yang diikuti oleh 30 orang mahasiswa dari berbagai disiplin ilmu (Peternakan, Ekonomi, Pertanian, Sosial Ekonomi Pertanian, Fisika, Biologi dan Matematika);

- Tahap 2, pembagian lokasi sasaran KKN-PPM bagi setiap mahasiswa;

- Tahap 3, pembagian peralatan dan perlengkapan kepada mahasiswa;

- Tahap 4, penempatan mahasiswa di lapangan;

- Tahap 5, pelaksanaan kegiatan di lapangan;

- Tahap 6, pelaksanaan monitoring dan evaluasi yang dilakukan pada pertengahan kegiatan dan akhir kegiatan;

- Tahap 7, penarikan mahasiswa dari lokasi sasaran untuk kembali ke kampus.

MATERI PERSIAPAN DAN PEMBEKALAN KKN-PPM

Materi yang diberikan kepada mahasiswa dalam pembekalan KKN-PPM terutama tentang bahan pakan untuk sapi potong yang baik, meliputi:

\section{(1) Pemanfaatan Bahan Pakan Potensial}

Limbah pertanian dan agroindustri pertanian memiliki potensi yang cukup besar sebagai sumber pakan ternak ruminansia. Limbah yang memiliki nilai nutrisi relatif tinggi digunakan sebagai pakan sumber energi atau protein, sedangkan limbah pertanian yang memiliki nilai nutrisi relatif rendah digolongkan sebagai pakan sumber serat. Kendala dalam memanfaatkan bahan pakan lokal diantaranya tidak adanya jaminan keseragaman mutu dan kontinuitas produksi. Disamping itu jumlah produksi bahan pakan lokal pada umumnya berskala kecil dan lokasinya terpencar. Pakan lokal selalu dikaitkan dengan harga yang murah. Beberapa hal yang perlu diperhatikan dalam penggunaan bahan pakan diantaranya, ketersediaan bahan, kadar gizi, harga, kemungkinan adanya faktor pembatas zat racun atau anti nutrisi serta perlu tidaknya bahan tersebut diolah sebelum digunakan sebagai pakan ternak. Sejak lama, berbagai penelitian telah dilakukan untuk optimalisasi pakan lokal yang belum lazim digunakan. Pertimbangan nilai ekonomis akibat adanya introduksi teknologi masih banyak dilupakan sehingga hasil penelitian belum dapat langsung diterapkan. Penjelasan beberapa hasil penelitian dan uji lapang tentang pemanfaatan bahan pakan limbah pertanian dan agroindustri potensial yang bernilai harga relatif murah pada usaha pembibitan sapi potong lokal (Bos indicus atau Bos sondaicus) seperti dedak, kulit kopi, kulit coklat, ketela pohon, dan hasil ikutannya, kulit kacang tanah, bungkil biji kapuk, kedele, dan hasil ikutannya dan limbah pertanian lain akan dilakukan.

\section{(2) Pengembangan Teknologi Pakan}

Produktivitas ternak dipengaruhi oleh faktor lingkungan sampai $70 \%$ dan faktor genetik hanya sekitar 30\%. Diantara faktor lingkungan tersebut, aspek pakan mempunyai pengaruh paling besar sekitar $60 \%$. Hal ini menunjukkan bahwa walaupun potensi genetik ternak tinggi, namun apabila pemberian pakan tidak memenuhi persyaratan kuantitas dan kualitas, maka produksi yang tinggi tidak akan tercapai. Disamping pengaruhnya yang besar terhadap produktivitas ternak, faktor pakan juga merupakan biaya produksi yang terbesar dalam usaha peternakan. Biaya pakan ini dapat mencapai $60-80 \%$ dari keseluruhan biaya produksi. Pakan utama ternak ruminansia adalah hijauan yaitu sekitar 60-70\%; namun demikian karena ketersediaan pakan hijauan terbatas maka pengembangan peternakan dapat diintegrasikan dengan usaha pertanian sebagai strategi dalam penyediaan pakan ternak melalui optimalisasi pemanfaatan limbah pertanian dan limbah agroindustri pertanian. Sumber pakan ternak sapi berupa hijauan seperti rumput (rumput gajah, rumput lapangan, dan lain-lain); dan limbah pertanian seperti jerami (jerami padi, jerami jagung, jerami kedelai, dan lain-lain), daun-daunan (nangka, pisang, kelapa sawit, dan lain-lain), limbah industri (bagase tebu, kulit kacang, tumpi jagung, kulit kopi, dan lain-lain). Pakan yang baik adalah 
murah, mudah didapat, tidak beracun, disukai ternak, mudah diberikan dan tidak berdampak negatif terhadap produksi dan kesehatan ternak serta lingkungan.

\section{(3) Pakan Komplit}

Salah satu pengembangan teknologi formulasi pakan adalah adanya pakan komplit, yaitu semua bahan pakan yang terdiri atas hijauan dan konsentrat dicampur menjadi satu campuran yang homogen dan diberikan kepada ternak sebagai satu-satunya pakan tanpa tambahan rumput segar. Formulasi pakan mudah diduplikasi di setiap sentra peternakan dengan memanfaatkan potensi bahan pakan lokal dengan menggunakan mesin pencampur sederhana serta ramah lingkungan sehingga harganya sangat murah. Formulasi pakan diharapkan banyak digunakan untuk pengembangan sapi potong penggemukan/ pembibitan di wilayah yang tidak tersedia pakan hijauan sepanjang tahun. Kandungan nutrisi konsentrat yang dikembangkan adalah kadar air maks 15\%; protein kasar 9-12\%; lemak kasar maks 4\%; serat kasar 20\%; abu maks 10\%; TDN min 60\%; Ca $1,0 \%$ dan $\mathrm{P} 0,5 \%$.

\section{(4) Konsentrat}

Konsentrat adalah suatu bahan pakan dengan nilai gizi tinggi yang dipergunakan bersama bahan pakan lain untuk meningkatkan keserasian gizi dari keseluruhan pakan dan digunakan sebagai sebagai pelengkap (suplemen). Konsentrat sapi potong tidak selalu berbentuk konsentrat buatan pabrik atau yang dijual di pasaran (konsentrat komersial); namun dapat berupa bahan pakan tunggal atau campuran beberapa bahan pakan. Fungsi utama konsentrat adalah untuk mencukupi kebutuhan protein, karbohidrat, lemak dan mineral yang tidak dapat dipenuhi oleh hijauan (Eniza, 2004). Introduksi penggunaan konsentrat sapi potong banyak digunakan untuk usaha penggemukan. Pada sapi induk dianjurkan sebesar 1-1,5\% bobot badan. Untuk menekan biaya ransum, pemberian konsentrat dapat dikombinasikan dengan bahan pakan limbah agroindustri potensial setempat. Pemanfaatan bahan pakan setempat dapat menggantikan konsentrat komersial sampai dengan $75 \%$. Penggunaan konsentrat murah lebih dianjurkan untuk pengembangan sapi potong di wilayah potensial bahan pakan limbah pertanian atau agroindustri pertanian berkualitas rendah diantaranya potensial limbah jerami padi, jerami jagung, dedak padi, tumpi jagung, kulit kopi, kulit kacang dan lain-lain.

\section{JADWAL PELAKSANAAN KEGIATAN KKN-PPM}

Sesuai dengan tahapan kegiatan yang diuraikan di atas, maka kegiatan KKN- PPM mahasiswa adalah 2,5 - 3 bulan yang terdiri dari persiapan sampai dengan penempatan mahasiswa di lapang selama 2 (dua) minggu; kegiatan efektif di lapang selama 2 (dua) bulan atau 60 hari kalender; pembuatan laporan dan penyampaian laporan (termasuk seminar, diskusi dan perbaikan laporan) selama 2 (dua) minggu.

\section{PELAKSANAAN}

\section{BIMBINGAN TEKNIS PEMELIHARAAN SAPI POTONG}

Peserta Bimbingan Teknis :

Sebagai peserta bimbingan teknis dipilih petani yang memelihara sapi dalam suatu kelompok dengan jumlah peserta sebanyak 50 orang.

Hasil yang diharapkan :

Petani mampu secara mandiri memelihara sapi potong dengan standar pemeliharaan yang baik.

\section{TEKNIK MEMBUAT KONSENTRAT}

\section{Metode:}

Bahan pakan yang digunakan untuk pembuatan konsentrat adalah limbah pertanian dan limbah dari industri pangan yang tersedia di Distrik Prafi. Bahan-bahan tersebut terdiri atas dedak padi, ampas tahu, onggok/cassava, garam dan urea. Prosedur pembuatan konsentrat sebagai berikut :

1. Bahan konsentrat kering seperti dedak padi, garam dan urea dicampur terlebih dahulu hingga merata;

2. Setelah langkah pertama selesai, maka selanjutnya onggok dicampur ke dalam dedak padi. Diaduk secara perlahan hingga homogen; 
3. Bahan konsentrat terakhir yaitu ampas tahu dicampur ke dalam bahan-bahan tersebut hingga homogen; selanjutnya konsentrat yang sudah siap diberikan pada sapi.

Persentase bahan pakan yang digunakan untuk pembuatan konsentrat serta komposisi kimia konsentrat disajikan pada Tabel 1. Formulasi tersebut dibuat dengan mempertimbangkan ketersediaan bahan pakan di lokasi KKN PPM.

Tabel 1. Persentase bahan pakan dalam konsentrat untuk sapi

\begin{tabular}{lcc}
\hline Bahan Pakan & Persentase Bahan Pakan & Jumlah (Kg) \\
\hline Dedak padi & 70 & 4,0 \\
Onggok & 16 & 4,8 \\
Ampas tahu & 11 & 4,5 \\
Garam & 2 & 0,7 \\
Urea & 1 & 0,5 \\
\hline Jumlah & 100 & 14,3 \\
\hline
\end{tabular}

\section{PENYULUHAN KEPADA PETERNAK SAPI}

Metode yang digunakan dalam bentuk ceramah, diskusi, pemutaran slide atau film yang berhubungan konsentrat sapi potong.

Hasil yang diharapkan :

Pengetahuan dan pemahaman tentang konsentrat dan bahan-bahan penyusunnya semakin bertambah.

Volume pekerjaan setiap mahasiswa dihitung berdasarkan Jam Kerja Efektif Mahasiswa (JKEM) yakni sebanyak 38 JKEM per minggu atau 144 JKEM per bulan (lihat tabel). Pada kegiatan KKN-PPM ini yang dilakukan selama dua bulan maka volume pekerjaan setiap mahasiswa adalah 288 JKEM.

Tabel 2. Volume Pekerjaan

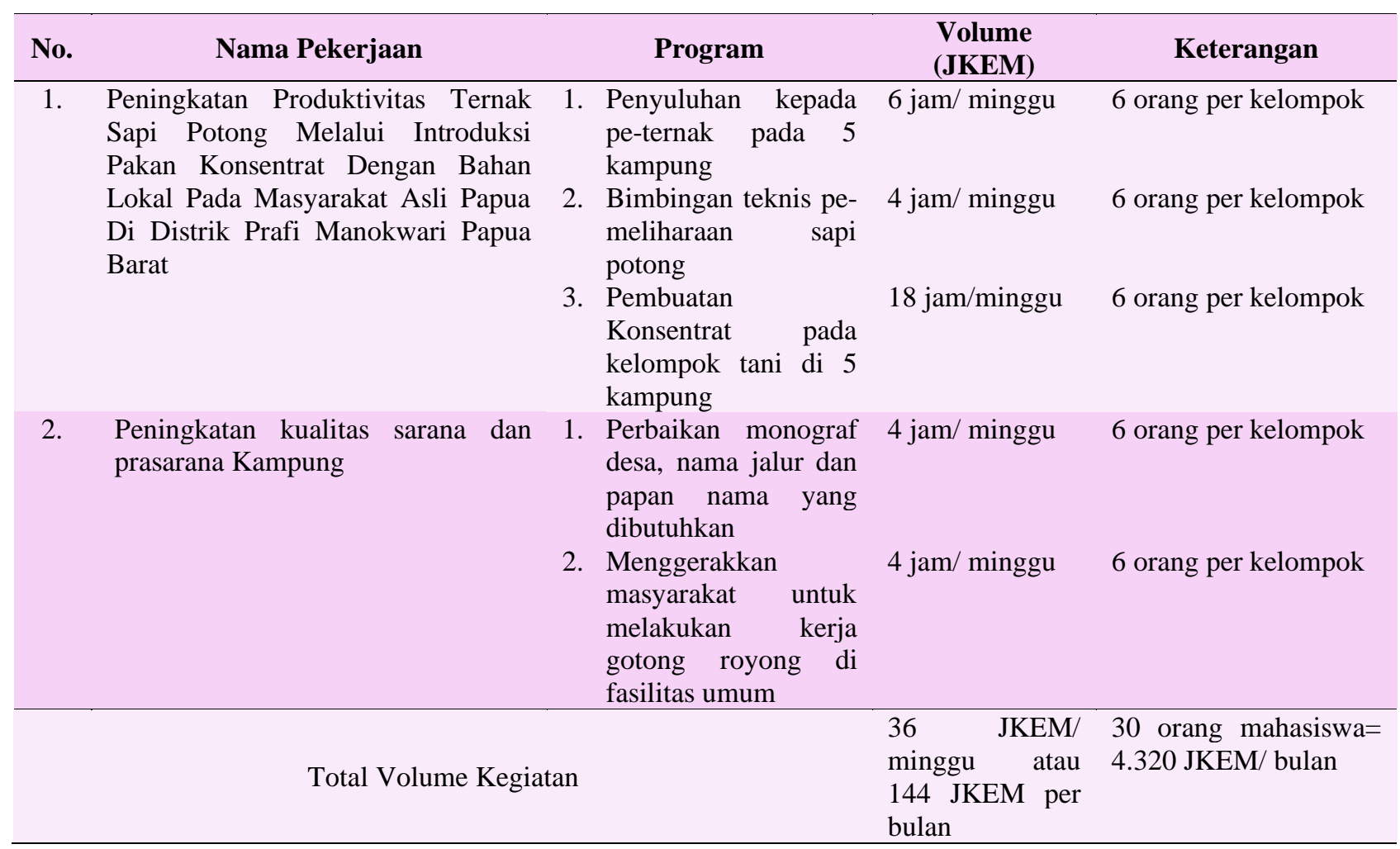




\section{HASIL DAN PEMBAHASAN}

Kegiatan KKN-PPM terdiri dari kegiatan utama (tematik) yaitu pembuatan konsentrat untuk sapi potong dan kegiatan pendukung yaitu kegiatan pembenahan sarana prasarana kampung. Kegiatan pendukung merupakan hasil kesepakatan dengan aparat kampung, tokoh masyarakat, tokoh agama dan tokoh adat di setiap kampung.

Program kegiatan utama yaitu pembuatan konsentrat telah dilakukan kepada peternak setelah terlebih dahulu mahasiswa memberikan penyuluhan tentang bahan-bahan pakan lokal yang dapat dijadikan pakan tambahan seperti dedak padi, onggok, ampas sagu, kulit coklat dan ampas tahu. Dalam pelaksanaannya mahasiswa membuat konsentrat dari bahan-bahan yang tersedia setiap saat yaitu dedak padi (70\%), onggok (16\%), ampas tahu (11\%), garam (2\%) dan urea (1\%). Konsentrat dibuat dalam keadaan segar dan tidak membutuhkan bahan kimia atau sentuhan teknologi yang tidak terjangkau oleh masyarakat.

Proses pembuatan konentrat dilakukan dengan cara menimbang bahan-bahan dedak sebanyak 4 $\mathrm{kg}$, onggok 4,8 kg, ampas tahu 4,5 kg, garam $0,7 \mathrm{~kg}$ dan urea $0,5 \mathrm{~kg}$. Bahan-bahan pakan yang kering seperti dedak, garam dan urea dicampur terlebih dahulu kemudian ditambahkan onggok dan terakhir adalah ampas tahu. Konsentrat yang sudah siap dengan berat total $14,3 \mathrm{~kg}$ diberikan pada 7 ekor sapi sesuai dengan bobot tubuh sebanyak $1-2 \%$ dari bobot badan tiap sapi. Laryska dan Nurhajati (2013) menyatakan bahwa pakan berupa rumput bagi sapi dewasa umumnya diberikan sebanyak 10\% dari bobot badan dan pakan tambahan sebanyak 1-2\% dari berat badan.

Konsentrat dibuat satu kali per minggu untuk diberikan pada 7 ekor sapi. Selama kegiatan KKN-PPM, total konsentat yang dibuat sebanyak $114,4 \mathrm{~kg}$. Pada kegiatan ini tidak dilakukan penimbangan bobot badan pada sapi-sapi yang diberi pakan konsentrat. Namun demikian, nampak adanya perubahan bobot badan setelah sapi mengkonsumsi konsentrat disbanding sapi-sapi yang tidak mengkonsumsi konsentrat.

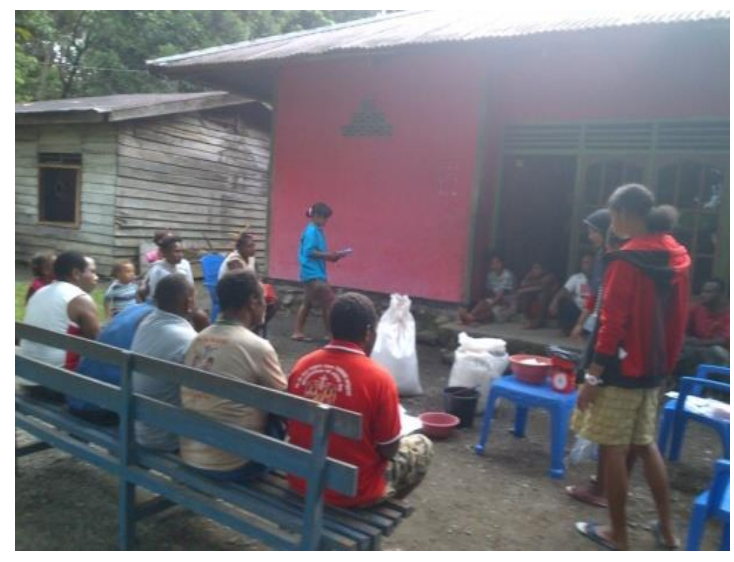

Gambar 1. Pelatihan pembuatan konsentrat

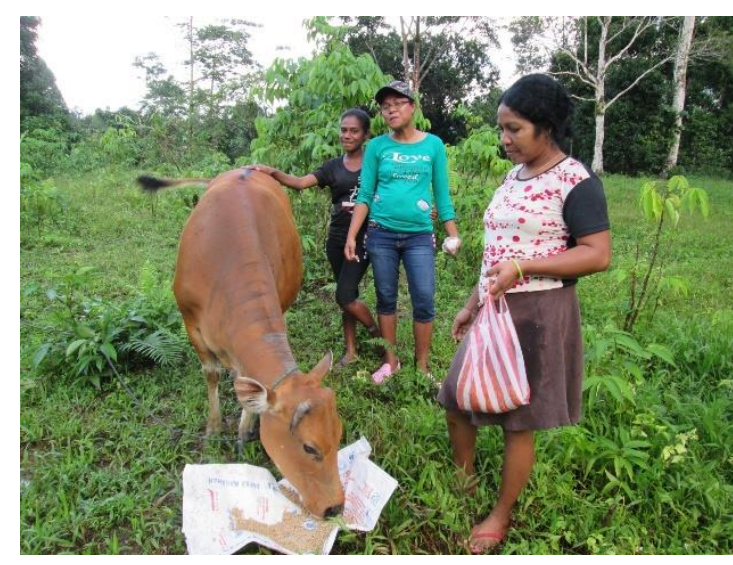

Gambar 2. Uji coba pada sapi

Sapi-sapi yang tidak terbiasa dengan konsentrat, pada awalnya menolak dan hanya mencium pakan tersebut, akan tetapi ketika hijauan diberikan secara terbatas, sapi pada akhirnya mengkonsumsi konsentrat tersebut. Sistem pemeliharaan ekstensif dengan cara mengumbar sapi di areal lahan kelapa sawit, menyulitkan program kegiatan ini karena sapi-sapi sama sekali tidak mau mengkonsumsi. Beberapa peternak yang mengkandangkan dan atau mengikat sapi miliknya, membantu kerja mahasiswa untuk melaksanakan program pembuatan konsentrat ini. Wahyono dan Hardianto (2004) menyatakan bahwa keunggulan pengembangan pakan berbasis bahan baku lokal antara lain harga lebih murah dengan kualitas standard, mudah dalam pengumpulan bahan baku dan distribusi produk, nilai tambah dari kegiatan prosesing pakan diperoleh langsung para peternak, serta dapat menumbuhkan embrio usaha agroinput pada skala usaha kecil dan menengah di daerahdaerah sentra produksi sapi potong. 
Seluruh program kerja terlaksana dengan baik, dengan persentase rata-rata keberhasilan yaitu 96,25\%. Hasil ini sesuai dengan kegiatan pemberdayaan masyarakat melalui pengembangan dan penguatan kelompok pembudidaya ikan (POKDAKAN) air tawar Desa Sepanjang Kecamatan Gondanglegi Kabupaten Malang yang dilaksanakan oleh KKN PPM Kelompok 03 UMM yang mencapai $100 \%$ (Sutarjo dan Warkoyo, 2019). Secara umum, program kerja tersebut dibagi dalam sembilan bidang, yaitu: sarana dan prasarana, pendidikan dan keterampilan, kesehatan dan lingkungan hidup, sosial budaya dan spiritual, administrasi pemerintah kampung, ekonomi, pertanian, peternakan, serta bidang lainnya.

Pelaksanaan program kerja mahasiswa KKN di Kampung Waseki Pop, memiliki beberapa kendala yakni pendidikan, kesehatan, dan pemerintah kampung yang belum berfungsi secara optimal serta rendahnya partisipasi warga terhadap program penyuluhan, yang dipengaruhi oleh kebiasaan warga menghabiskan sebagian besar waktunya untuk bertani dan berdagang hasil kebunnya.

Secara umum, tim mahasiswa KKN-PPM tidak memperoleh hambatan yang berarti dalam melaksanakan program utama yaitu pembuatan konsentrat. Bahan baku yag dibutuhkan seperti dedak padi, onggok, garam dan urea mudah diperoleh disekitar kampung. Faktor pendukung yang berperan dalam kegiatan KKN-PPM adalah kekompakan tim, dukungan masyarakat, dan tersedianya bahan-bahan konsentrat maupun bahan-bahan lain dalam pelaksanakan program KKNPPM. Djawad et al (2019) dalam melaksanakan kegiatan KKN-PPM dengan tema pemberdayaan masyarakat melalui pengurangan resiko bencana berbasis teknologi informasi untuk pembudayaan sikap, keterampilan, dan strategi adaptasi dalam menghadapi bencana di daerah pesisir pantai kabupaten Bulukumba juga menemukan faktor pendukung (adanya dukungan dari pihak sekolah yang cukup baik) dan faktor penghambat (terbatasnya alat transportasi yang dimiliki oleh anggota KKN-PPM).

\section{KESIMPULAN}

Konsentrat yang dibuat untuk masyarakat di Kampung Waseki Pop pada distrik Prafi berasal dari bahan-bahan lokal yang mudah diperoleh. Tidak terdapat sentuhan teknologi tinggi dalam pembuatan konsentrat sehingga mudah dilakukan oleh masyarakat walau tidak ada mahasiswa yang mendampingi. Dari kegiatan yang telah dilakukan, nampak bahwa masyarakat sangat antusias dalam membuat konsentrat. masyarakat peternak memahami pentingnya pakan tambahan (konsentrat) untuk sapi-sapi yang dimilikinya.

Berdasarkan kegiatan KKN yang telah dilakukan di kampung Waseki Pop Distrik Prafi maka disarankan:

1. Perlu adanya kerjasama dengan instansi-instansi terkait dalam perencanaan dan realisasi kegiatan KKN.

2. Masyarakat perlu meningkatkan kesadaran dan partisipasi dalam kegiatan KKN yang dilaksanakan di setiap kampung.

3. Diharapkan setiap Kepala Kampung dapat menghimbau masyarakatnya agar ikut serta dalam kegiatan sekaligus menjaga dan merawat hasil kerja mahasiswa KKN.

4. Pemahaman tugas-tugas pemerintahan dalam setiap kampung perlu ditingkatkan.

\section{UCAPAN TERIMA KASIH}

Penulis mengucapkan terimakasih kepada Direktorat Penelitian dan Pengabdian Kepada Masyarakat yang telah mendanai kegiatan KKN-PPM. Penulis juga menyampaikan terimakasih.

\section{DAFTAR PUSTAKA}

Abutani, S.A, Rahim, S, dan Noverma. 2010. Respon Pemberian "Blok Suplemen" Berbasis Bahan Lokal Terhadap Pertambahan Bobot Sapi Bali. Jurnal Sain Peternakan Indonesia. 5 (1): 65 69 
Djawad, Y.A, Jaya, H, Saliruddin dan Supriadi. 2019. Pemberdayaan Siswa SMK Melalui Pelatihan Penerapan Alat Deteksi Banjir Berbasis IOT di Kab. Bulukumba Melalui Program KKN PPM. Jurnal Mekom, 6 (2): 101-107.

Eniza Saleh. 2004. Dasar Pengolahan Susu dan Hasil Ikutan Ternak. Program Studi Produksi Ternak Fakultas Pertanian Universitas Sumatera Utara. Sumatera.

Handiwirawan, E dan Tiesnamurti B. 2015. Pertambahan Bobot Badan Sapi Bali dan PO yang Digemukkan Berdasarkan Skor Temperamen. Prosiding Seminar Nasional Teknologi Peternakan dan Veteriner 2015: 27-33.

Laryska, N dan Nurhajati, T. 2013. Peningkatan Kadar Lemak Susu Sapi Perah dengan Pemberian Pakan Konsentrat Komersial Dibandingkan dengan Ampas Tahu. AGROVETERINER. 1 (2): 79-87.

Mariyono dan Romjali, E., 2007. Petunjuk teknis teknologi inovasi Pakan murah untuk usaha pembibitan sapi potong. Pusat Penelitian dan Pengembangan Peternakan. Jakarta.

Nanda D.D, Purnomoadi, A dan Nuswantara, L.K, 2014. Penampilan Produksi Sapi Bali yang Diberi Pakan Dengan Berbagai Level Pelepah Sawit. Agromedia. 32 (2): 54-63.

Rauf, A, Priyanto, R, dan Dewi P, 2015. Produktivitas Sapi Bali pada Sistem Penggembalaan di Kabupaten Bombana. Jurnal Ilmu Produksi dan Teknologi Hasil Peternakan. 03 (2): 100-105.

Sari, DDK, Astuti, MH dan Asi, LS, 2016. Pengaruh Pakan Tambahan Berupa Ampas Tahu dan Limbah Bioetanol Berbahan Singkong (Manihot utilissima) Terhadap Penampilan Sapi Bali (Bos sondaicus). Buletin Peternakan. 40 (2): 107-112.

Soemarmi, A. Musofie, and N. K. Wardhani. 1985. Effect of sugar cane top on daily weight gain of male Bali cattle. Proc. Seminar the Use of Sugarcane Waste for Animal Feed. Grati. Center Research in Animal Science.

Sutarjo, G.A dan Warkoyo. 2019. KKN PPM Pemberdayaan Masyarakat Melalui Pengembangan dan Penguatan Kelompok Pembudidaya Ikan (Pokdakan) Air Tawar Desa Sepanjang Kecamatan Gondanglegi Kabupaten Malang. Jurnal Dedikasi. 16: 13-16.

Wayono, D.E dan Hardianto, R. 2004. Pemanfaatan Sumberdaya Pakan Lokal untuk Pengembangan Usaha Sapi Potong. Lokakarya Nasional Sapi Potong. p: 66-76. 